\title{
EFFECT OF USING LEMONGRASS AND THYME ON SOME BEEFBURGER CHARACTERISTICS
}

\author{
HUSSEIN, SANAA A., MF.S.A. SHAHIN and M.R.M. MASOUD
}

\author{
Food Technol. Res. Inst., ARC, Giza - Egypt
}

(Manuscript received 24 December 2014)

\begin{abstract}
$\mathrm{T}$

his study was carried out to evaluate beefburger prepared by $2 \%$ lemongrass, $2 \%$ thyme, $1 \%$ from lemongrass plus thyme and $0.5 \%$ from lemongrass and thyme addition in relative to control beefburger without addition. (moisture, protein, fat, ash and total carbohydrates) were determined in raw materials (lemongrass and thyme), beefburger and their formulas during storage period. Thiobarbituric acid, the total volatile nitrogen, $\mathrm{pH}$ values, water holding capacity, plasticity cooking loss, cooking yield, shrinkage and total bacterial count were determined in beefburger and their formulas during storage period for 3 months at $-18^{\circ} \mathrm{C}$. Moreover organoleptic characteristics were determined in fresh beefburger and their formulas.

The results showed that the moisture and protein were decreased by increasing storage period as well as total lipids, ash, crude fibers and total carbohydrates were increased. Storage deteriorated both plasticity and WHC. Shrinkage and cooking loss increased by storage. For the supplemented samples, the best formula was recorded in case of the lemongrass/thyme mixture, specially at the lower ratio (0.5). The best supplemented sample were recorded in the lemongrass group. Cooking yield decreased by storage and the best supplemented sample was that of the individual lemongrass group. As the storage period increased, the total volatile nitrogen (TVN) and thiobarbituric acid (TBA) values increased for all beefburger and their formulas, samples.

During the storage period, the control beefburger showed the highest of total bacterial count . While, their formulas reported that the lowest in total bacterial count were in $2 \%$ lemongrass formula, followed by $(1 \%+1 \%)$ lemongrass and thyme formula and then $2 \%$ thyme formula. The organoleptic evaluations showed that the formula contained $2 \%$ lemongrass gave the best acceptability (36.0) followed by the formula contained equal weight $(1 \%)$ of both lemongrass and thyme (32.0). Moreover, the formula prepared from $2 \%$ thyme have a medium acceptability (30.0) as well as the formula contained equal weight $(0.5 \%)$ of both lemongrass and thyme which showed the lowest overall acceptability.

It can be recommended that the lemongrass and thyme can play an important role as antioxidant and antibacterial agents in refrigerated beefburger and their formulas, but lemongrass is the best one.
\end{abstract}




\section{INTRODUCTION}

Spices and herbs have been added to food since ancient times, not only as flavoring agents, but also as a folk medicine and food preservatives (Cutler, 1995). Spices occupy a prominent place in the traditional culinary practices and are indispensable part of daily diets of millions of people all over the world. They are, essentially, flavoring agents used in small amounts and are reported to have both beneficial effect and antimicrobial properties (Oluwafemi, 2000).

Thyme is commonly used in foods, mainly, for its flavor and aroma. Also, thymol, which is found in thyme, has been commercially available as a part of mouthwash for more than hundred years. Besides, it is active against E. coli and St. aureus and spoilage flora in meat products (Solomakos et. al., 2008).

Lemon grass (Cymbopogon citrates) is a rich source of citral, which is used in perfumery and pharmaceutical industries, and bioactive compounds (flavonides and vitamin $\mathrm{C}$ ). The natural flavonides are also attracting more and more attention not only due to their antioxidant properties, but as anti-carcinogenic and antiinflammatory agents because of their lipid anti-peroxidation effects (Martin et. al., 2002).

Lemongrass (Cymbopogon citratus) is a perennial and aromatic tall tropical grass that is commonly used as herbs for flu, headache, malaria, coughs elephantiasis, pneumonia digestive problems, diarrhea, stomach upsets and vascular disorders (Ozer et. al., 1995). Olorunsanya et. al., (2010) evaluated The antioxidative potential of ground lemongrass (Cymbopogon citratus) at graded levels on raw and cooked pork patties, under refrigeration for 9 and 6 days for raw and cooked, respectively, in a $5 \times 2 \times 4$ factorial experiment. In $200 \mathrm{~g}$ pork patties $0,0.5,1.0$ or $1.5 \%$ lemongrass were added and a reference control was prepared with $200 \mathrm{mg}$ tocopherol acetate in $200 \mathrm{~g}$ pork patties. Results showed that raw pork patties with lemongrass had lower TBARS values than the control or tocopherol treated pork patties. Raw pork patties treated with any level of lemongrass had lower TBARS values than their cooked counterparts. Addition of $1.5 \%$ lemongrass was effective in reducing lipid oxidation in raw patties under refrigeration. Lemongrass can conveniently replace synthetic antioxidant such as BHA, BHT and TBHQ that consumers have worry for due to their health safety.

Herbs have been used for a large range of purposes including medicine, nutrition, flavorings, beverages, dyeing, repellents, fragrances, cosmetics, charms, smoking, and industrial uses. Since prehistoric times, herbs were the basis for of nearly all medicinal therapy until synthetic drugs were developed in the nineteenth 
century. Today herbs are still found in 40 percent of prescription drugs (Smith and Winder, 1996).

The aim of this study is to evaluate the effects of added lemongrass and thyme in beefburger on its quality attributes and estimate the antimicrobial effect during storage period for 3 months. Chemical analysis, physical characteristics, microbiological analysis and sensory evaluation were determined in formulae contained different concentrations of lemongrass, thyme and mixtures of them.

\section{MATERIALS AND METHODS}

\section{Materials}

Imported Brazil beef (frozen) and fat tissues (sheep tail) were purchased from the private sector shop in the local market at Giza, Egypt.

Lemongrass and thyme were obtained from the Horticultural Research Institute, Agric. Res. Center, Giza - Egypt. Total Plate Count agar media was obtained from Difco Co.

\section{Methods}

\section{Preparation of beefburger and their formulae}

Beef burger control and added lemongrass, thyme and mixtures of them were mixed with the other ingredients to prepare the final mixture to manufacture four formulae. The ingredients of the control and tested formulae are shown in Table (1).

Table 1. The ingredients (as\%) of control beef burger and other tested formulae.

\begin{tabular}{|c|c|c|c|c|c|}
\hline Recipes & Control & Formula 1 & Formula 2 & Formula 3 & Formula 4 \\
\hline Beef meat & 67.0 & 67.0 & 67.0 & 67.0 & 67.0 \\
\hline Sheep fat & 8.0 & 8.0 & 8.0 & 8.0 & 8.0 \\
\hline Lemongrass * & - & 2 & - & 1 & 0.5 \\
\hline Thyme* & - & - & 2 & 1 & 0.5 \\
\hline Onion & 7.0 & 7.0 & 7.0 & 7.0 & 7.0 \\
\hline Salt & 2.0 & 2.0 & 2.0 & 2.0 & 2.0 \\
\hline Rusk & 5.0 & 5.0 & 5.0 & 5.0 & 5.0 \\
\hline Spices & 1.0 & 1.0 & 1.0 & 1.0 & 1.0 \\
\hline Ice water & 10.0 & 10.0 & 10.0 & 10.0 & 10.0 \\
\hline
\end{tabular}

* Added to the final mixture. 
Minced beef meat and other ingredients were homogenized manually, after that the batch of about $1 \mathrm{~kg}$ was manually, cut and rounded in about $50 \mathrm{~g}$ tec each pieces and finally formed using Hollymatic machine (Model 2004). Beefburgers and their formulae were kept in plastic bags and stored at $-18^{\circ} \mathrm{C}$ for three months.

\section{Chemical analyses of the tested beefburger and their formulae}

Chemical analyses (moisture, protein, fat and ash) were determined in raw materials (lemongrass and thyme), beefburger and their formulae during the storage period according to AOAC (2005) methods. Total carbohydrates were calculated by the difference method (summing the values of moisture, crude protein, ash and crude fat ether extract and subtracting the sum from 100) according to McDonald et. al., (1973). Thiobarbituric acid (TBA) and the total volatile nitrogen (TVN) of beefburger samples were determined using the method published by Kirk and Sawyer (1991). The $\mathrm{pH}$ values measured using $\mathrm{pH}$-meter model Consort $\mathrm{P} 107$, were determined in the beefburger and their formulae during storage period according to the method described by Defreitas et. al., (1997).

\section{Physical analyses of the tested beefburger and their formulae}

Water Holding Capacity (WHC) and plasticity in the beef burger and their formulae were measured during storage period according to the filter press method of Soloviev (1966). The cooking loss of beefburger and their formulae during storage period was determined as the method described by AMSA (1995) and the cooking yield was calculated. Shrinkage (\%) of the tested samples was determined after frying at $180^{\circ} \mathrm{C}$ as equation. [(Fresh sample diameter) - (Fried sample diameter) / (Fresh sample diameter) $\times 100]$.

\section{Organoleptic evaluation of beefburger and their formulae}

Organoleptic evaluation of beefburger and their formulae were determined by the method described by Morr (1970).

\section{Microbiological analysis}

Total bacterial count (TBC) of beefburger and their formulae, during storage period, a was determined according to American Public Health Association (1992).

\section{Statistical analysis}

The obtained data of sensory evaluation were analyzed by using SPSS statistical software (version 13 SPSS Inc., Chicago. USA). The results were expressed 
as mean $\pm S D$, and tested for significance using one-way analysis of variance "ANOVA" according to Armitage and Berry (1987).

\section{RESULTS AND DISCUSSION}

\section{Chemical compositions of raw materials and beefburger formulae during storage period}

Moisture, ash, total protein, lipids, crude fibers and total carbohydrates were determined in lemongrass, thyme, beefburger as the control sample and other their formulaes, and the results are reported in Table (2). From the results in Table (2), it could be noticed that the lemongrass contained a higher protein (17.5\%) amount than that formula thyme (9.10\%). The moisture, ash, lipid and crude fibers seemed to be equal in both.

The resultant beefburgers as a control sample and their formulae showed that the moisture and protein decreased by increasing storage period, while crude fibers and total lipids increased by increasing the storage period. The decrease of total protein in beefburger and their formulae may be due to the activation effect of microbial load which may cause protein hydrolysis with the appearances of alkyl groups (Yassin, Nessrien 2003). The changes in total carbohydrates of beefburger and their formulae may be related to some other changes in different chemical constituents. Moreover, the gradual percentage increases in ash, crude fibers and total lipids for beefburger and their formulae during storage period may be caused by the lemongrass and thyme containing increased high amount from ash, crude fibers and total lipids (11.17, 19.50 and $10.0 \%$ on wet weight lemongrass and $11.70,18.60$ and $7.40 \%$ on wet weight thyme, respectively). 
Table 2. Chemical compositions (as\%) of raw materials and their formulae of beef burger during storage period (three months) on wet weight basis.

\begin{tabular}{|c|c|c|c|c|c|c|c|}
\hline Formulae & $\begin{array}{l}\text { Storage } \\
\text { period in } \\
\text { months }\end{array}$ & Moisture & Protein & Lipids & Ash & $\begin{array}{l}\text { Crude } \\
\text { fibers }\end{array}$ & T.C. \\
\hline Lemongrass & - & 11.33 & 17.5 & 10.0 & 11.17 & 19.50 & 30.50 \\
\hline Thyme & - & 12.30 & 9.10 & 7.40 & 11.70 & 18.60 & 40.90 \\
\hline \multirow[t]{4}{*}{ Control } & 0 & 61.73 & 15.74 & 14.85 & 2.60 & 0.95 & 4.13 \\
\hline & 1 & 61.49 & 15.22 & 15.04 & 2.85 & 1.14 & 4.26 \\
\hline & 2 & 61.08 & 14.81 & 15.22 & 3.18 & 1.28 & 4.43 \\
\hline & 3 & 60.33 & 14.63 & 15.48 & 3.44 & 1.38 & 4.74 \\
\hline \multirow[t]{4}{*}{ Formulae 1} & 0 & 60.57 & 15.93 & 15.29 & 2.72 & 0.99 & 4.50 \\
\hline & 1 & $6 \cdot .13$ & 15.55 & 15.43 & 3.02 & 1.18 & 4.69 \\
\hline & 2 & 59.24 & 15.32 & 15.77 & 3.47 & 1.40 & 4.80 \\
\hline & 3 & 58.32 & 15.12 & 16.12 & 3.60 & 1.50 & 5.34 \\
\hline \multirow[t]{4}{*}{ Formulae 2} & 0 & 60.71 & 15.69 & 14.93 & 2.73 & 0.97 & 4.97 \\
\hline & 1 & 60.29 & 15.32 & 15.13 & 3.10 & 1.16 & 5.00 \\
\hline & 2 & 59.27 & 15.14 & 15.52 & 3.41 & 1.31 & 5.35 \\
\hline & 3 & 58.35 & 15.00 & 15.90 & 3.67 & 1.47 & 5.61 \\
\hline \multirow[t]{4}{*}{ Formulae 3} & 0 & 60.65 & 15.80 & 14.94 & 2.71 & 0.98 & 4.92 \\
\hline & 1 & $6 \cdot .12$ & 15.41 & 15.17 & 3.08 & 1.17 & 5.05 \\
\hline & 2 & 59.22 & 15.18 & 15.75 & 3.26 & 1.35 & 5.24 \\
\hline & 3 & 59.33 & 15.11 & 15.95 & 3.59 & 1.48 & .5 .54 \\
\hline \multirow[t]{4}{*}{ Formulae 4} & 0 & 61.10 & 15.76 & 14.70 & 2.65 & 0.95 & 4.84 \\
\hline & 1 & $6 \cdot .75$ & 15.10 & 15.12 & 2.85 & 1.15 & 5.03 \\
\hline & 2 & 60.22 & 14.80 & 15.35 & 3.18 & 1.32 & 5.13 \\
\hline & 3 & 59.43 & 14.66 & 15.57 & 3.49 & 1.39 & 5.46 \\
\hline
\end{tabular}

Control beefburger without any additives.

T. C. Total Carbohydrates.

Formula 1 Prepared from beefburger control sample plus $2 \%$ lemongrass.

Formula 2 Prepared from beefburger control sample plus $2 \%$ thyme.

Formula 3 Prepared of beefburger control sample plus 1\% lemongrass and $1 \%$ thyme.

Formula 4 Prepared of beefburger control sample plus $0.5 \%$ lemongrass and $0.5 \%$ thyme.

\section{Physical characteristics of beefburger and their formulae during storage period}

Water holding capacity (WHC) is one of the most important properties, including the eating quality, tenderness, juiciness, thawing drip and cooking loss of meat and meat products. Water holding capacity (WHC), plasticity, shrinkage, cooking loss and cooking yield were determined in beefburger and their formulae during storage period, and the results are reported in Table (3). The results data showed that the plasticity and WHC in beefburger as control was evident at zero time, and gradually decreased during storage. During the storage period, the lowest plasticity 
and WHC value was recorded in case of the lemongrass/thyme at the lowest ratio $(0.5 \%+0.5 \%)$ addition. The control beefburger and other formulae made contained $0.5 \%$ of both lemongrass and thyme samplees showed the highest plasticity and WHC beef- burger during storage period compared with other formulae.

The data presented in Table (3) showed that the shrinkage and cooking loss in beefburger and their formulae decreased during storage period as reported by Wolf (1970) who found that the protein binds fat and its solubility reduces by storage. Concerning cooking yield, it was higher for beefburger at zero time and decreased during storage period than control beef burger. The increase in the cooking yield among supplemented samples was specially recorded for lemongrass group samples.

Table 3. Physical characteristics of beef burger and their formulae during storage period (three months)

\begin{tabular}{|c|c|c|c|c|c|c|}
\hline Formulae & $\begin{array}{c}\text { Storage } \\
\text { period in } \\
\text { months }\end{array}$ & $\begin{array}{l}\text { Plasticity } \\
\left(\mathrm{cm}^{2} / 0.3 \mathrm{~g}\right)\end{array}$ & $\begin{array}{c}\text { WHC } \\
\left(\mathrm{cm}^{2} / 0.3 \mathrm{~g}\right)\end{array}$ & $\begin{array}{c}\text { Shrinkage } \\
\%\end{array}$ & $\begin{array}{l}\text { Cooking } \\
\text { loss \% }\end{array}$ & $\begin{array}{l}\text { Cooking } \\
\text { yield \% }\end{array}$ \\
\hline \multirow[t]{4}{*}{ Control } & 0 & 2.65 & 3.15 & 15.50 & 22.82 & 77.18 \\
\hline & 1 & 2.40 & 3.81 & 16.20 & 23.24 & 76.76 \\
\hline & 2 & 2.23 & 4.47 & 17.50 & 25.91 & 74.09 \\
\hline & 3 & 2.02 & 4.95 & 18.50 & 28.88 & 71.12 \\
\hline \multirow[t]{4}{*}{ Formulae 1} & 0 & 2.64 & 3.21 & 15.43 & 21.32 & 78.68 \\
\hline & 1 & 2.35 & 3.84 & 15.90 & 23.02 & 76.98 \\
\hline & 2 & 2.12 & 4.60 & 16.10 & 24.60 & 75.40 \\
\hline & 3 & 1.70 & 5.25 & 16.50 & 26.30 & 73.70 \\
\hline \multirow[t]{4}{*}{ Formulae 2} & 0 & 2.62 & 3.17 & 15.45 & 21.30 & 78.70 \\
\hline & 1 & 2.39 & 3.72 & 15.92 & 23.22 & 76.78 \\
\hline & 2 & 2.11 & 4.66 & 16.15 & 24.85 & 75.15 \\
\hline & 3 & 1.86 & 5.20 & 16.55 & 26.45 & 73.55 \\
\hline \multirow[t]{4}{*}{ Formulae 3} & 0 & 2.63 & 3.16 & 15.46 & 21.31 & 78.69 \\
\hline & 1 & 2.37 & 3.70 & 15.95 & 23.19 & 76.81 \\
\hline & 2 & 2.10 & 4.65 & 16.20 & 24.70 & 75.30 \\
\hline & 3 & 1.90 & 5.15 & 16.60 & 26.49 & 73.51 \\
\hline \multirow[t]{4}{*}{ Formulae 4} & 0 & 2.71 & 3.16 & 15.48 & 21.34 & 78.66 \\
\hline & 1 & 2.38 & 3.85 & 16.15 & 23.36 & 76.64 \\
\hline & 2 & 2.21 & 4.50 & 17.45 & 25.14 & 74.86 \\
\hline & 3 & 2.00 & 4.99 & 18.40 & 27.80 & 72.20 \\
\hline
\end{tabular}

WHC Water holding capacity. 


\section{Chemical induce on the beefburger and their formulae during storage period}

The mean values of total volatile nitrogen (TVN) are summarized in Table (4) estimating the degree of meat deterioration during the storage period. As the storage period increased, the TVN values increased for all beefburger and their formulae. This may be attributed to the breakdown of proteins as a result of activity of microbial strains and proteolytic enzymes (Yassin, Nessrien 2003). EOS (2005) stated that 20 $\mathrm{mg}$ TVN/ $100 \mathrm{~g}$ in raw samples indicates the spoilage of minced meat. The highest TVN values was recorded in the beefburger formula contained equal weight $(0.5 \%)$ of both lemongrass and thyme. The formulae contained $2 \%$ lemongrass or $(2 \%)$ thyme or equal weight $(1 \%)$ of both lemongrass and thyme, were more gradient effective in delaying the rate of TVN increase during the subsequent cold storage. This may be attributed to the role of these herbs on microbial population and bacterial growth as antimicrobial agents.

The levels of thiobarbituric acid (TBA) mean values of beefburger control and their formulae samples during storage period are shown in Table (4). The highest incremental rate was recorded in the beefburger as control followed by formula, which seemed to be the same value, contained equal weight $(0.5 \%)$ of lemongrass and thyme. Whereas, the lowest incremental rate was recorded in formula contained $2 \%$ lemongrass, followed by formulae contained $2 \%$ of both thyme and $1 \%$ of both lemongrass and thyme were the same results. The incremental pattern in TBA values for all the stored samples with advancing the chilling storage time may be affected by the anti-oxidation of meat lipids, bacteriological and/or oxidative rancidity. The differences in $\mathrm{pH}$ mean values in beef burger as control and their formulae samples during storage period are illustrated in the Table (4). The results showed that the lowest incremental rates of $\mathrm{pH}$ values were found in the samples contained $2 \%$ lemongrass followed by that contained $2 \%$ thyme. It may due to the lemongrass are a rich source of citrus which possessed an acidity taste and caused decreasing in the $\mathrm{pH}$ values compared with beefburger control. 
Table 4. Mean values of the chemical quality parameters of the beefburgers and their formulae during storage period (three months)

\begin{tabular}{|c|c|c|c|c|}
\hline Formulae & $\begin{array}{l}\text { Storage period in } \\
\text { months }\end{array}$ & TVN (mg/100g) & $\begin{array}{c}\text { TBA } \\
(\mathrm{mg} / 100 \mathrm{~g})\end{array}$ & $\mathrm{pH}$ values \\
\hline \multirow[t]{4}{*}{ Control } & 0 & 9.24 & 0.26 & 5.73 \\
\hline & 1 & 11.45 & 0.33 & 5.77 \\
\hline & 2 & 14.02 & 0.48 & 5.81 \\
\hline & 3 & 18.76 & 0.61 & 5.92 \\
\hline \multirow[t]{4}{*}{ Formulae 1} & 0 & 9.14 & 0.22 & 5.73 \\
\hline & 1 & 9.92 & 0.26 & 5.62 \\
\hline & 2 & 12.54 & 0.34 & 5.61 \\
\hline & 3 & 16.15 & 0.51 & 5.60 \\
\hline \multirow[t]{4}{*}{ Formulae 2} & 0 & 9.19 & 0.24 & 5.73 \\
\hline & 1 & 10.15 & 0.28 & 5.74 \\
\hline & 2 & 12.85 & 0.41 & 5.77 \\
\hline & 3 & 16.75 & 0.56 & 5.79 \\
\hline \multirow[t]{4}{*}{ Formulae 3} & 0 & 9.17 & 0.23 & 5.73 \\
\hline & 1 & 10.06 & 0.26 & 5.68 \\
\hline & 2 & 12.61 & 0.38 & 5.67 \\
\hline & 3 & 16.42 & 0.54 & 5.64 \\
\hline \multirow[t]{4}{*}{ Formulae 4} & 0 & 9.21 & 0.25 & 5.73 \\
\hline & 1 & 11.20 & 0.30 & 5.71 \\
\hline & 2 & 13.92 & 0.45 & 5.70 \\
\hline & 3 & 17.02 & 0.58 & 5.69 \\
\hline
\end{tabular}

\section{Organoleptic properties of beefburger and their formulae}

Organoleptic evaluations of aroma, taste, color, texture, and overall acceptability were estimated in the tested beefburger and their formulae after cooking and the results are given in Table (5). From the resultant data, it was found that the formula made from $2 \%$ lemongrass gave the best acceptability $(36.0)$ followed by the formula contained equal weight (1\%) of both lemongrass and thyme (32.0). Moreover, the formula prepared from $2 \%$ thyme have a medium acceptability (30.0) as well as the formula contained equal weight $(0.5 \%)$ of both lemongrass and thyme showed the lowest overall acceptability (but not rejected; about $70 \%$ of total score). 
Table 5. Organoleptic properties of beefburger and their formulae

\begin{tabular}{|c|c|c|c|c|c|}
\hline Formulae & Aroma & Taste & Color & Texture & Overall acceptability \\
\hline Control & $\begin{array}{l}9.00^{\mathrm{a}} \\
\pm 0.12^{\mathrm{a}}\end{array}$ & $\begin{array}{l}9.00^{\mathrm{a}} \\
\pm 0.10\end{array}$ & $\begin{array}{l}9.00^{\mathrm{a}} \\
\pm 0.11\end{array}$ & $\begin{array}{l}9.00^{\mathrm{a}} \\
\pm 0.11\end{array}$ & 36.0 \\
\hline Formula 1 & $\begin{array}{l}9.00^{\mathrm{a}} \\
\pm 0.14 \\
\end{array}$ & $\begin{array}{l}9.00^{\mathrm{a}} \\
\pm 0.12 \\
\end{array}$ & $\begin{array}{l}9.00^{\mathrm{a}} \\
\pm 0.12 \\
\end{array}$ & $\begin{array}{l}9.00^{\mathrm{a}} \\
\pm 0.12 \\
\end{array}$ & 36.0 \\
\hline Formula 2 & $\begin{array}{l}7.00^{b} \\
\pm 0.15\end{array}$ & $\begin{array}{l}7.00^{b} \\
\pm 0.16\end{array}$ & $\begin{array}{l}8.00^{\mathrm{b}} \\
\pm 0.15\end{array}$ & $\begin{array}{l}8.00^{\mathrm{b}} \\
\pm 0.14\end{array}$ & 30.0 \\
\hline Formula 3 & $\begin{array}{l}8.00^{\mathrm{ab}} \\
\pm 0.12\end{array}$ & $\begin{array}{l}8.00^{\mathrm{ab}} \\
\pm 0.13\end{array}$ & $\begin{array}{l}8.00^{\mathrm{b}} \\
\pm 0.13\end{array}$ & $\begin{array}{l}8.00^{\mathrm{b}} \\
\pm 0.14\end{array}$ & 32.0 \\
\hline Formula 4 & $\begin{array}{r}6.00^{c} \\
\pm 0.15\end{array}$ & $\begin{array}{r}6.00^{c} \\
\pm 0.15\end{array}$ & $\begin{array}{l}8.00^{\mathrm{b}} \\
\pm 0.14\end{array}$ & $\begin{array}{l}8.00^{\mathrm{b}} \\
\pm 0.13\end{array}$ & 28.0 \\
\hline
\end{tabular}

Each mean value, within the same column, followed by the same letter is not significant at 0.05 level.

\section{Microbiological analysis of beefburger and their formulae}

Table (6) results show the total bacterial count of beefburger and their formulae during storage period. During $0,1,2,3$ months storage, the control beefburger showed values of total bacterial counts of $99,141,213$ and $305 \times 10^{3} \mathrm{CFU}$, respectively. While, their formulae total bacterial counts amounted to 94, 102, 120 and $150 \times 10^{3} \mathrm{CFU}$, respectively, in lemongrass formula, 97, 109, 127 and $167 \times 10^{3}$ CFU, respectively, in thyme (\%) formula, 96, 108, 125 and $161 \times 10^{3} \mathrm{CFU}$, respectively, in $1 \%$ of both lemongrass and thyme formula and 97, 132, 182 and $210 \times 10^{3} \mathrm{CFU}$, respectively, in $0.5 \%$ of both lemongrass and thyme formula, for the same storage periods. The relatively high initial counts of control samples may be attributed to the grinding process, which introducing the pathogens into the interior of the meat and contributes to the increase of total viable counts of the products (Mead and Griffin, 1998).

Table 6. Total count $\left(\times 10^{3} \mathrm{CFU}\right)$ of beefburger and their formulae during storage period.

\begin{tabular}{|c|c|c|c|c|}
\hline Formulae & $\begin{array}{c}\text { Zero time } \\
\times 10^{3}\end{array}$ & $\begin{array}{c}\text { After one month } \\
\times 10^{3}\end{array}$ & $\begin{array}{c}\text { After two months } \\
\times 10^{3}\end{array}$ & $\begin{array}{c}\text { After three months } \\
\times 10^{3}\end{array}$ \\
\hline Control & 99 & 141 & 213 & 305 \\
\hline Formula 1 & 94 & 102 & 120 & 150 \\
\hline Formula 2 & 97 & 109 & 127 & 167 \\
\hline Formula 3 & 96 & 108 & 125 & 161 \\
\hline Formula 4 & 97 & 132 & 182 & 210 \\
\hline
\end{tabular}




\section{CONCLUSION}

It is suggested that thyme and lemongrass can be used as natural meat preservatives with both antioxidants and antimicrobial activities against food borne pathogens and spoilage organisms, and therefore may be useful in maintaining the meat quality, extending shelf- life of meat products, preventing economic loss and providing the consumer with food containing natural additives, which are considered more healthful than those of synthetic origin.

\section{REFERENCES}

1. American Public Health Association. 1992. Standard Methods for the Examination of Dairy Products. American Pub1. Health Assoc. Inc. $16^{\text {th }}$ Ed., Washington D.C.

2. AMSA, 1995. Research Guidelines for Cookery, Sensory Evaluation and Instrumental Tenderness Measurements of Fresh Beef. American Meat Science Assoc., Chicago, U.S.A.

3. AOAC 2005. Official Methods of Analysis of the Association of Official Analytical Chemists, $18^{\text {th }}$ ed., Washington, D.C.

4. Armitage, P and G. Berry. 1987. Statistical Method in Medical Research. Blackwell, Oxford, UK, PP: 93-213.

5. Cutler, H.G. 1995. Natural product flavor compounds as potential antimicrobials, insecticides, and medicinals. Agro-Food Ind. Hi-Tech., 6: 19-23.

6. Defreitas, Z., J. G. Sebranek, D. G. Olson, and J. M. Carr. 1997. Freeze/thaw stability of cooked pork sausages as affected by salt, phosphate, $\mathrm{pH}$ and carrageenan. J. Food Sci., 62(3):551-554.

7. EOS. 2005. Egyptian Organization for Standardization and Quality: Egyptian Standard, ES.

8. Kirk, R.S and R. Sawyer. 1991. Pearson's Compsition and Analysis of Foods. $9^{\text {th }}$ Edn., AWL, Harlow.

9. Martin, F. R., M. J. Frutos, J. A. Pérez - Alvarez, F. Martinez - Sánchez and J. A. Tel Rio. 2002. Flavonoids as neutraceutical: Structural related antioxidant properties and their role on ascorbic acid preservation. In: Atta Ur-Rahman (Ed.), Studies in natural products chemistry, 26: 324-389.

10. McDonald, P., R.A. Edwards, and J.F.D. Green-halgh. 1973. Animal Nutrition. T and A Constable Ltd., Edinburgh, PP: 2-5.

11. Mead, P. S. and P. G.Griffin. 1998. Escherichia coli O157:H7. The Lancet vol. 352, October 10. 
12. Morr, M.L. 1970. Introductory Food, Laboratory Manual of Food Preparation and Evaluation. $2^{\text {nd }}$ Ed. Mac Millan Pub. Co. Inc., New York, Coclier Mac Millan Pub., London.

13. Olorunsanya, A. O., E. O. Olorunsanya, S. A. O. Bolu, C. T. Adejumobi, and R. M. O. Kayode, (2010). Effect of graded levels of lemongrass (Cymbopogon citratus) on oxidative stability of raw or cooked pork patties. Pakistan Journal of Nutrition, 9 (5): 467-470.

14. Oluwafemi, F. 2000. Correlation Between Dietary Aflatoxins and Human Male Infertility. Ph.D. Thesis, University of Benin.

15. Ozer, N.K., D. Boscoboinik, and A. Azzi. 1995. New roles of low density lipoprotein and vitamin $\mathrm{E}$ in the pathogenesis of atherosclerosis. Biochem. Mol. Biol. Int., 35: 117-24.

16. Smith, R.J. and M.L. Winder. 1996. Medicinal Garden. P. 61-71. In: R. Ober (ed), The National Herb Garden Guidebook; The Herb Society of America, Inc., Springfield, VA.

17. Soloviev,V. E. 1966. Meat Aging. Food Industry. Pub., Moscow, PP: 53- 81.

18. Solomakos, N., A. Govaris, P. Koidis, and N. Botsoglou. 2008. The antimicrobial effect of thyme essential oil, nisin, and their combination against Listeria monocytogenes in minced beef during refrigerated storage. J. Food Microbiol., 25 (1): 120- 127.

19. Wolf, W. J. 1970. Soy protein : Their functional, chemical and physical properties. J. Agric. Food Chem., 18(6):969-976.

20. Yassin -Nessrien, M. N. 2003. Effect of Storage Conditions on the Quality Parameters of Differently Treated Fish. Ph. D. Thesis, Fac. Agric. Ain Shams, Univ. Cairo. Egypt. 


\section{تأثير أستخدام حشيشة الليمون والزعتر على بعض صفات بورجر اللحم}

سناء عبدالله حسين محمود فخر الدين سعد أحمد شاهين محمد رمضان محمد مسعود

$$
\text { معهد بحوث تكنولوجيا الأغذية - مركز البحوث الزراعية - جيزة - مصر }
$$

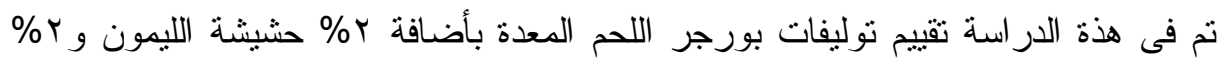
زعتر و ا \% و 0. •\% من كلا من حشيشة الليمون و الزعتر وبذلك تعطى أربعة توليفات مع العينة

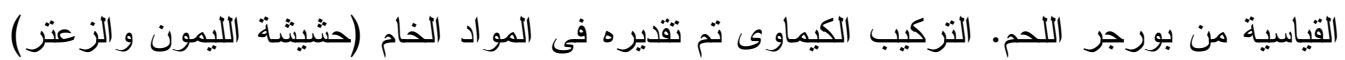
و عينة البورجر القياسية ونوليفاتها أثناء فتزة التخزين. حامض الثيوباربيتيورك و النتروجين المنطاير الكلى و الأس الأيدروجينى و القدرة على الاحتفاظ بالماء و البلاستيكية و الفقد أثثاء الطهى و العائد من

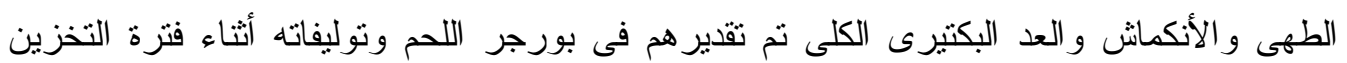

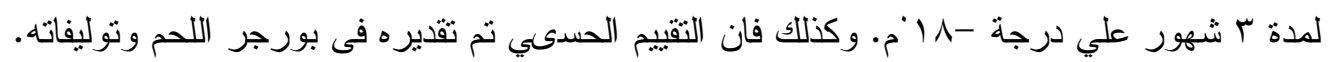
أوضحت النتائج أن الرطوبة و البروتين حدث لها أنخفاض بزيادة فترة النخزين في حين أن فئن

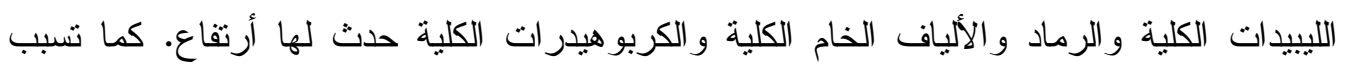

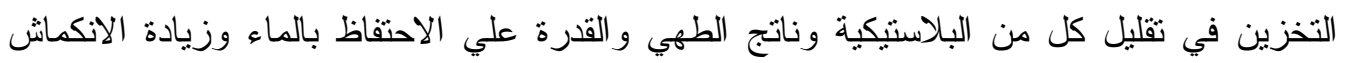

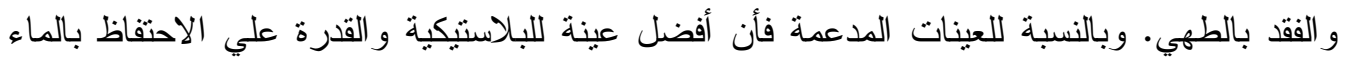

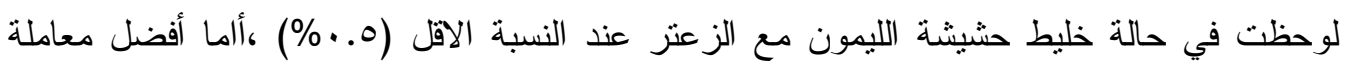
للانكماش و الفقد بالطهي ومقدار الناتج بالطهي كانت في حالة مجموعة حشيشة الليمون من بين العينات المعاملة. أما حامض الثيوباربيتيورك و النتروجين المنطاير الكلى فقد حدث لهم زيادة عند

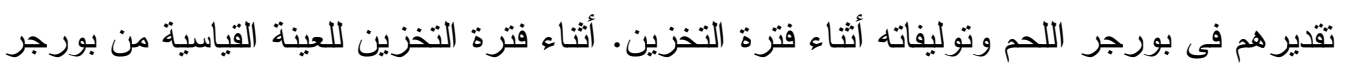

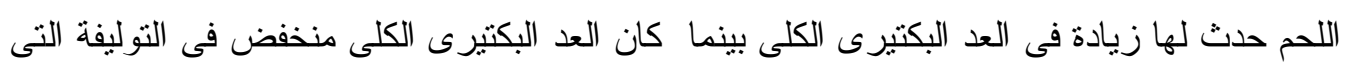

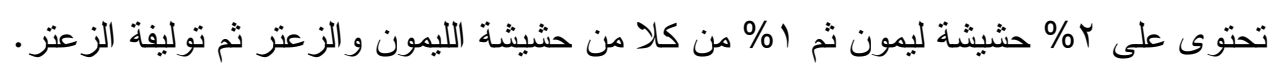

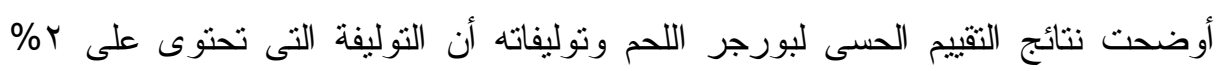

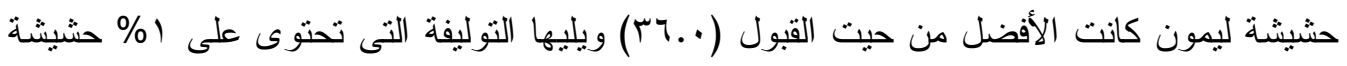

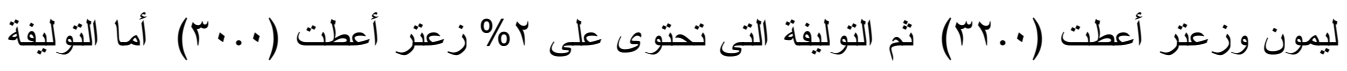

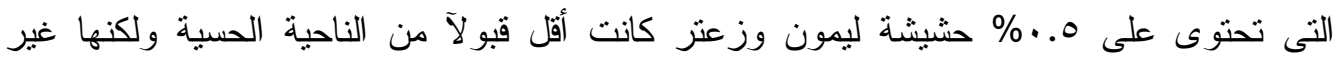

لللك يمكن أن نوصى بأن حشيشة الليمون والزعتر تلعب دورآ هامآ كمضادات أكسدة

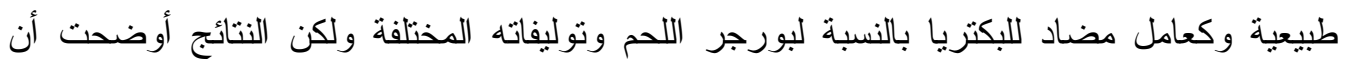
حشيشة الليمون كانت الأفضل. 